E. G. Moschetta, S. Negretti, K. M. ChepigA, N. A. BRUnelli, Y. LAbreche,

Y. FENG, F. REZAEI, R. P. LIVELY, W. J. KOROS, H. M. L. DAVIES, * C. W. JONES*

(GEORGIA INSTITUTE FOR TECHNOLOGY AND EMORY UNIVERSITY, ATLANTA, USA)

Composite Polymer/Oxide Hollow Fiber Contactors: Versatile and Scalable Flow Reactors for Heterogeneous

Catalytic Reactions in Organic Synthesis

Angew. Chem. Int. Ed. 2015, 54, 6470-6474.

\title{
Flow Reactors Using Hollow Fibers for Acid, Base, or Chiral Rhodium Catalysis
}

\section{Gategory}

Polymer-Supported

Synthesis

Key words

flow chemistry

heterogeneous

catalysis

hollow fibers

rhodium

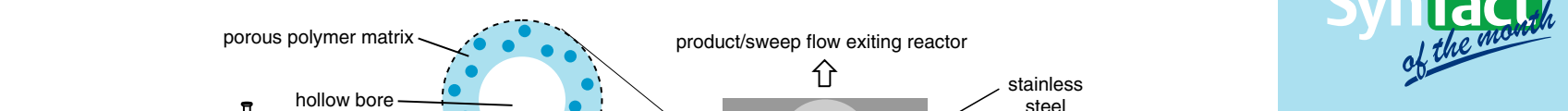

Selected examples:<smiles>COC(OC)c1ccccc1</smiles>

1

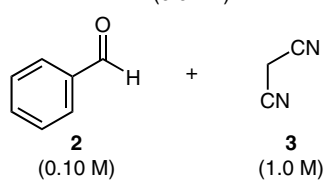<smiles>[2H]C(=[W])OC(C)=O</smiles>

5

$(0.1 \mathrm{mmol})$

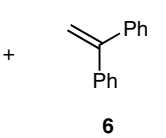

(3 mol equiv)

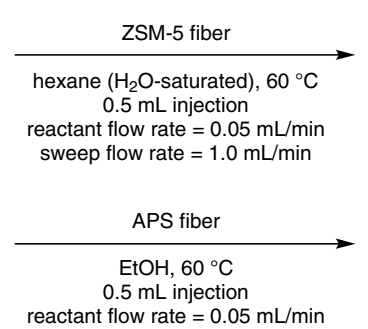

reactant flow rate $=0.05 \mathrm{~mL} / \mathrm{min}$
sweep flow rate $=1.0 \mathrm{~mL} / \mathrm{min}$

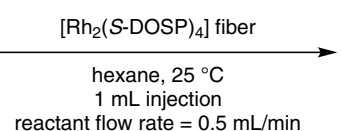

reactant flow rate $=0.5 \mathrm{~mL} / \mathrm{min}$

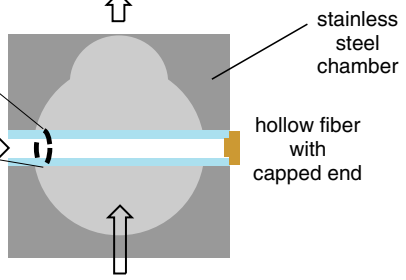

sweep flow into chamber

Significance: Flow reaction systems using composite hollow cellulose acetate fibers containing embedded catalysts ZZSM-5 (aluminosilicate MFI zeolite), 3-aminopropyl (APS)-functionalized silica, and the immobilized analogue of $\mathrm{Rh}_{2}(S \text {-DOSP })_{4}$ [DOSP $=N$-(4-dodecylphenylsulfonyl)prolinato] $\}$ were developed for heterogeneous catalytic reactions. The acid-catalyzed hydrolysis of (dimethoxymethyl)benzene (1) to benzaldehyde (2) on ZSM-5/fiber, the Knoevenagel condensation of benzaldehyde (2) with malononitrile (3) on APS fiber, and a rhodium-catalyzed enantioselective cyclopropanation on the $\mathrm{Rh}_{2}(S-D O S P)_{4}$ fiber all proceeded efficiently.
Comment: The catalysts were embedded within the permeable fiber walls (approximately 300-400 $\mu \mathrm{m}$ thick), and the reactants were fed through the bores of the composite hollow fibers. The fiber was surrounded by a sweeping flow of organic solvent that facilitated product collection. The fiber was capped at the end furthest from the inlet to ensure the reactants flowed through the walls and contacted to the catalyst. 